\title{
Upholding the Impartiality of Judges in Judicial Systems
}

\author{
Agus Nurudin \\ Faculty of Law, Universitas 17 Agustus 1945 Semarang, Indonesia. E-mail:ags_nurudin@yahoo.com
}

\begin{tabular}{l} 
ARTICLE INFO \\
\hline Keywords: \\
Impartiality Principle; \\
Judges; Judicial Systems; \\
Criminal Law \\
How to cite: \\
Nurudin, A. (2020). \\
Upholding the Impartiality \\
of Judges in Judicial \\
Systems. Hasanuddin Law \\
Review, 6 (1): 80-88 \\
DOI: \\
10.20956/halrev.v6i1.2268 \\
\end{tabular}

\begin{abstract}
Free and impartial justice is a characteristic and ideal of a constitutional State. In societies with a free and open judiciary system, individuals are permitted to challenge a judge's verdict, ability to remain impartial, and conduct. This article a doctrinal research with statute, comparative, and conceptual approaches. Meanwhile, data were analyzed descriptively, consisting of quotes. The results show that impartiality legal process (free from pressure, both physical and psychological and impartial) is a characteristic of a constitutional State. In the criminal justice system has received a full principle of free and impartial justice. At the lowest level, this principle in criminal justice is played by the judge as the core apparatus of judicial power, the principle of freedom and impartiality of judges in examining, hearing and deciding cases. The treatment in a crime must always be brought to the application of the principle of impartiality or treatment as referred in the principles of impartiality. Likewise, the principle of impartiality must not only be applied to suspects or defendants, it must be interpreted including the treatment of crown witnesses, victim witnesses and their families and also cannot be ignored about the existence of the community as legal subjects who have an interest in the implementation of public law.
\end{abstract}

Copyright $\odot 2020$ HALREV. All rights reserved.

\section{Introduction}

Free and impartial justice is a characteristic and ideal of a constitutional State. In the development of just law, it is necessary to implement an optimal legal system through the integration of legal instruments, legal culture, and law enforcers as the frontline in conducting law enforcement. ${ }^{1}$ The affirmation of Indonesia as a State based on law is

1 Contini, F., \& Mohr, R. (2007). Reconciling independence and accountability in judicial systems. Utrecht L. Rev., 3, 26. 
not only understood as a State with adequate written legal instruments, but more than, it must be supported by optimal legal instruments. Therefore, law cannot only be seen as something that is textual and finite scheme. The law must continue to move, change, and follow the dynamics of human life to ensure the orientation of law enforcement remains on the rail that has been outlined by the constitution as a legal ideal (rechtsidee). ${ }^{2}$

Departing from the law construction, all elements in conducting any action must be based on a law that can be accounted for. The optimal policy direction for law enforcement is most important and has a great influence in realizing just law. This is based on the consequences of the realization of the rule of law concept, in which everything must be based on law and also provide legal certainty. Hence, humans as main actors behind the life of the law are not only required to be able to create and making the law, but also the courage to breaking the law when the law is unable to bring the spirit and substance of its existence, namely creating harmony, peace, order and community welfare. ${ }^{3}$

Legal development leads to increased legal awareness, service and legal certainty and can realize a legal order that is dedicated and oriented towards national interests. This also provides an answer that legal development must lead to the formation of a legal system that is based on the socio-culture of a nation. Noting these things, in the development of a just law, it is necessary to run an optimal legal system through the integration of legal instruments, legal culture, and law enforcers as the frontline in conducting law enforcement.

The principle of impartiality as a main issue of this study give the meaning of "humanist", it is reflected in an inner attitude and outlook on life that is glorifying individual rights, treating all people equally, being fair and not prejudicing others. The word impartial comes from the English "impartiality" means a fair deal, this notion is then translated into Indonesian which is almost the same as the original. ${ }^{4}$ Impartiality is a mandate used to defend victims of human rights violations. It does not distinguish origins, social strata, race, religion or political direction of person. ${ }^{5}$

Although the term "impartiality" is more tended to be used in the field of law, but in its development, the term impartiality is also widely used in various aspects of life. On the other understanding, the notion of impartiality is a view of life that glorifying individual rights (and not ignoring communal rights). Thus, the principle of impartiality treats all people equally, fairly and not prejudges others, care to the disadvantaged people or victims of human rights violations. It can also mean as an order to provide protection for human rights. This principle is a very basic principle and should be used as a basis for law enforcement. 6

2 Tardjono, H. (2016). "Reorientasi Politik Hukum Pembentukan Undang-Undang di Indonesia." Jurnal Renaissance, Vol. 1, No. 2: 61-74.

3 Rahardjo, S. (2010). Penegakan Hukum Progresif, Kompas, Jakarta, p. 1

4 The Indonesian Big Dictionary. Offline. Downloaded on the website: http://pusatbahasa.diknas.go.id/kbbi/. Accessed on Friday, 2 March 2020.

5 Rima, F. (2019). "Fatamorgana Keadilan Hukum Dalam Prinsip The Rule of Law." Pergulatan Etika Indonesia, Seri Filsafat Atmajaya, p. 201.

6 Adiyaryani, N.N. (2017). Asas Independensi dan Imparsialitas Hakim Menurut Sistem Peradilan Pidana. Postgraduate Program, Brawijaya University. 
Impartial legal process (free from pressure both physical and psychological and impartial) is a characteristic of a constitutional State. ${ }^{7}$ But it cannot be denied, there are many questions that are directed at the judiciary in Indonesia. An impression that the law can be directed to an important conclusion in economic or dominant political power, it is still inherent in the public's perception of the judicial system and process.

In the context of criminal law, the problem of the judge' freedom lies in determining the type of criminal, how the legislator gives their freedom in determining the type, size and method of criminal conduct (strafsoort, strafmaatdan strafmodus or strafmodaliteit). ${ }^{8}$ The freedom of judge is a form of freedom of judicial authority, even though it is not without risk. In the name of freedom, judges can abuse their freedom and can also act arbitrarily. To prevent the abuse of power, boundaries must be created without compromising the principle of freedom as the essence of judicial power. ${ }^{9}$ Thus, it is necessary to elaborate the principle of consistent impartiality, so that it can restore the spirit of judge's freedom in deciding cases.

\section{Method of Research}

This article a doctrinal research with statute, comparative, and conceptual approaches. Meanwhile, data were analyzed descriptively, consisting of quotes. Examiing the law as conceptualized in the rule of law according to the doctrine of positivism or normative research. ${ }^{10}$ It is analytical-descriptive by describing the conception of impartiality by the judge in deciding a case.

\section{Relationship of the Concept of Independence and Judge' Freedom}

The judge' freedom in giving decisions is in line with the legislation which requires judges as law enforcers and justice to explore, follow and understand the legal values that live in the community. A principle states that the court must not refuse to examine and try a case filed with him/her, on the grounds that the law is not or less clear, but rather obliged to examine and try it. This principle is based on the view that court organs can understand the law.

Formulation and development of thoughts on the principles of good justice has been formulated in the International Judicial Conference forum in Bangalore, India, 2001. This forum produced an agreement on the draft code of ethics and behavior of judges worldwide, and later called The Bangalore Draft. ${ }^{11}$ Finally, this draft was accepted by various judges in the world as a guideline together with the official designation of The Bangalore Principles of Judicial Conduct. In it contained 6 (six) main principles that must be used as a guide for judges in the world, namely: (1) independence; (2) impartiality; (3) integrity; (4) propriety; (5) equality; (6) competence and diligence.

7 Sibarani, S. (2018). Analisis Hukum Terhadap Korban Salah Tangkap (Error In Persona) Dalam Putusan No. 2161 K/PID/2012, Jurnal Justitia et Pax, Vol 34, No 2: 271-88.

8 Bawangun, A. (2014). "Pertanggungjawaban Kode Etik Hakim dalam Memutuskan Perkara Pidana." Lex Crimen Vol. 3, No. 2: 86-92.

9 Sorik, S., Nasution, M., and Nazaruddin. (2018). "Eksistensi Majelis Kehormatan Mahkamah Konstitusi (Studi Keputusan Majelis Kehormatan Mahkamah Konstitusi Nomor 01/MKMK/ X/2013)." Jurnal Konstitusi Vol. 15, No. 3: 666-87.

10 Ibrahim, J. (2005). Teori dan Metode Penelitian Hukum Normatif, Malang: Bayumedia Publishing, p. 47.

11 Asshiddiqie, J. (2006). Pengantar Ilmu Hukum Tata Negara Jilid II. Jakarta: Sekretariat Jenderal dan Kepaniteraan Mahkamah Konstitusi RI, p. 53 
The independence of the judiciary can be tested through two things, i.e impartiality and political insularity. ${ }^{12}$ Impartiality of the judge is seen in the idea that the judges will base their decisions on the law and facts at the trial, not on the basis of relation with one of the lawsuit parties. Impartiality of the judge is indeed not something that can be easily detected, where it can only be traced from their behavior as long as become judge vis-a-vis its relationship with the lawsuit in the context of social or political relations.

Impartiality of the judicial process can only be done, if the judge can exit from conflicts of interest or collegial factor with the lawsuit. Therefore, the judge must resign from the trial process if he/she sees the potential for impartiality. In the context of the Indonesian legal system, the judge must resign if he/ she has a relationship with one of the lawsuit parties or examined before the court. Termination of relations with the political world is important for a judge so that he/she does not become a tool to realize political goals or prevent the implementation of a political decision. Accountability in the judiciary is a necessity to support the creation of independence and professionalism and to overcome the problems of the judicial mafia. ${ }^{13}$

In the concept of judicial independence, it can be understood that the independence of judiciary must be balanced with judicial accountability. In this relation arises the concept of judicial accountability including integrity and transparency, as built on the principle of harmonization between legal responsibility and social responsibility. ${ }^{14}$ The consequence of judicial accountability is the supervision of the judiciary including the behavior of judges. In relation to the judge's duties, aspects of accountability, moral integrity and ethics, transparency, impartiality, professionalism and supervision are signs of recognition of the judge' freedom and independence.

Judge independence comes from the word "independence of the judiciary" which is equated with the term "independence judicial power". ${ }^{15}$ According to Bagir Manan, ${ }^{16}$ the judicial power is essentially free. The main task of the judicial power is to accept, examine and try and resolve each case submitted. In trying and resolving every case of judicial power must be free, free to judge and the influence of anything and anyone. It is inherent in the judicial power that it is free.

Judicial power is waiting, passive. If no case is filed to the judge, then the judge is waiting, waiting for the case to come or bringing the case to him/her (wo kein Klager ist, ist kein Richter). ${ }^{17}$ To better guarantee the objectivity of the judicial power, the trial hearing is open to the public, except if the law stipulates otherwise. Failure to fulfill this provision will invalidate the decision by the law.

Robbers, 18 in a book entitled "An Introduction to German Law" mentioned two meanings contained in the freedom of judges: the first; no one, especially the government or administrative officials can determine the sentence that the judge must impose. The

12 Larkins, C.M. (1996). Judicial Independence and Democratization: A Theoretical and Conceptual Analysis. The American Journal of Comparative Law. Vol XLIV (4).

13 Arief, B.N. (2001). Masalah Penegakan Hukum \& Kebijakan Penanggulangan Kejahatan. Bandung: Citra Aditya Bakti. p. 35

14 Goesniadhie, K. (2009). Prinsip Pengawasan Independensi Hakim. Makalah Hukum. Fakultas Hukum Universitas Wisnuwardhana. Malang. p. 8

15 Muchsin. (2004), Kekuasaan Kehakiman yang Merdeka \& Kebijakan Asasi, STIH IBLAM, Depok, p. 14.

16 Manan, B. (1995). Kekuasaan Kehaikman Republik Indonesia, Pusat Penerbitan Universitas LPPM Universitas Islam Bandung, Bandung, p. 23

17 Ibid

18 Robbers, G. (2003). An Introduction to German Law, 2003, 3 th ed, p. 27 
second; the implementation of judicial duties must not have personal consequences for the judge. He explicitly mentions two meanings of judges' freedom, but contextually there are 3 (three) essences of judge' freedom, namely:

a. Judges are only subject to law and justice

b. No one including the government can determine or direct judges. Judges are only subject to law and justice.

c. There is no personal consequences for the judge

The independent judicial power must be interpreted as not to intervention from anyone, including that cause fear from the judges to examine and decide a case. In Indonesia, the judicial bodies that exercise judicial power are the Supreme Court, the Constitutional Court and lower court that are administered by the Supreme Court. Similar understanding with different coverage becomes a general understanding of judicial power in each country (universal). All judicial bodies, from the highest to the lowest level are State instrument because these bodies act and decide for and on behalf of the State.

The essence of a judge' freedom is if a judge in exercise their duties and authority is free in exploring, following and understanding the legal values that live in society and from various influences and interests both inside and outside, including their own interests for the sake of upholding the law and justice. The legal mission carried by the judge as Radbruch's thesis ${ }^{19}$ is the judge in the ideal (das sollen) and the empirical (das sein) realms. The duties of judge is to draw the ideal into the empirical realms as if the existing laws in the world of reality are urged to follow the existing laws in the world of ideas as intended by natural law. According to Mertukusomo ${ }^{20}$ states that several principles of the judge' freedom are the courts tried according to law without differentiating people. In the front of law, everyone is equal (equality before the law). The court tried according to law. It gives judges more freedom.

Judges may not refuse to examine and try a case that is filed due to the law is unclear, but it is obligatory to examine and try it. Therefore, even though the judge was waiting or passive in the sense of not looking for a case, but once the case was filed, he/she was obliged to examine and try to the end. If the laws are incomplete or non-existent then he/she must find the law to interpreting, exploring, following and understanding the values of the law that lives in community.

Judges are considered to know the law (ius curia novit). The judge must be creative. All courts examine and decide cases with a panel of at least three people with the aim to better guarantee objectivity, but do not rule out the possibility to examine and decide with a single judge (unus judex). The parties or defendants have the right to deny (recussatie) the judge who hears the case. If a judge is still bound by blood relations to third degree, one of the members of judge, prosecutors, legal advisors or clerks in a particular case must resign from the examination of the case (excusatie). All decision of the judge must be accompanied by decision reasons.

Decision of the court must be objective and authoritative. Therefore, it must be supported by reasons or considerations why the judge decides that. The reason or consideration is the responsibility of the judge to the public for the decision. Any

19 Mochtar, Z.A. (2015). "Antinomi dalam Peraturan Perundang-undangan di Indonesia." Hasanuddin Law Review Vol. 1, No. 3: 316-36.

20 Mertukusomo, S. (2005). Mengenal Hukum, Suatu Pengantar, Liberty, Yogyakarta, p. 45 
objection to a process or a judge's decision can only be made solely according to the provisions regarding the procedure for court proceedings called legal remedies.

\section{Challenge in Upholding the Principle of Impartiality by Judges}

An independent judicial power is needed to be impartiality and fairness in deciding cases, including cases that directly or indirectly involve the interests of other branches of power. The court or judge must be independent not only from other branches of power, but also with the parties involved in the case. An independent judicial power is seen as an important element even as a substantive characteristic of a constitutional State and democracy or a democratic-state State (democratiesche rechsstaat).

Interventions of judicial authority can be conducted directly and indirectly. Direct intervention is conducted by obstructing or stopping the ongoing judicial process. While, indirect intervention is conducted by creating certain rules that will regulate restrictions and ways of interfering with the judicial authority. Another indirect way is to cause anxiety, fear, and others, such as fear of being acted upon, humiliated and so forth.

To guarantee the independent judicial authority, other than by developing a repressive system, it is no less important to develop a preventive system directly or indirectly, which can affect the independent judicial power. Direct prevention can be a prohibition to intervene process and decision of the judge, including decisions that do not have permanent legal force. Interference with judicial power decisions that do not yet have legal force will still lead to and threaten impartiality and fairness in court proceedings and decisions.

The first, in an ontological review, the principle of impartiality is an exclusive right held by a judge. But in its development, this principle experiencing a shift towards the expansion of meaning, so that when someone talks about the importance of applying the principle of impartiality, this attitude must be interpreted to apply to all law enforcement officials and all law enforcement institutions.

The second, in an epistemological review, the way to apply the principle of impartiality of judges, through the judges' beliefs, as it comes from the conscience of the judge. It cannot be denied that the belief that comes from the conscience of the judge, sometimes it cannot be applied consistently because the belief that grows in the conscience of judge must come from at least two valid evidences. The acquisition of two legal evidences begins with the collection of legal evidence by the investigator.

The third, in an axiological review, this is related to the large number of court processes that are considered by the community to be unfair trials, causes unfair court decisions. This fact occurs as a juridical implication of not applying the principle of impartiality consequently since the beginning of the legal process. Furthermore, a theoreticalphilosophical problem, the principle of impartiality of judges (including other law enforcers) is recognized in the Indonesian criminal justice system. But at the practical level, its implementation has not been fully applied in accordance with the theory.

Finally and more important is juridical problem in applying impartiality principles. There are vague of norms regarding the principle of independence and impartiality of judges or other law enforcers particularly in criminal procedural law, it has not been clearly formulated in the articles of Act No. 8 of 1981 concerning criminal procedural 
law, as well as the vacuum of norms regarding the principle of impartiality of judges or other law enforcers.

In an effort to realize a correct and fair decision in the criminal justice process, the judge must always base their actions on the principle of impartiality. ${ }^{21}$ The principle of impartiality as a basis for judges in realizes legal and criminal goals. This includes the purpose of criminal procedure law, as a patron to search for and find material truth in a criminal case. The search and discovery of material truth will not be realized if it is not supported by a fair process from the beginning of the criminal proceedings, namely since the act of inquiry, investigation, arrest and/or detention, pre-prosecution, prosecution and trial.

A main problem in the application of the principle of impartiality is what if the inquiry, investigation and prosecution are performed in a way that does not apply the principle of impartiality? It certainly will get invalid results. If investigation is performed with violence, threats of violence both physically and psychologically or other means such as injury time examination, where witnesses or suspects experience physical or psychological fatigue, it will result in providing invalid and inaccurate information even information that is "indifferent". If left, this will have implications for the collapse of judicial authority.

The judge' freedom in their capacity as an individual has freedom as a perfection of their existence as a human being. A coercion, bonding, burden is an alienation that suppress man in such a way as to obstruct the implementation of himself as a whole and independent human being. 22 Humans as individual creatures have freedom as the perfection of their existence. If it is said that every human being wants freedom for himself, then what is meant by this statement is not freedom in the sense of "free from all obligations or fears of responsibility" but freedom as the meaning of existence as a human being, independence as a human being.

Freedom as a way and purpose of life as a human being is freedom that the person is free from various kinds of alienation that suppresses him and free also for a whole, impeccable, self-reliant and creative life, in the sense of freedom as the perfection of human existence. According to Albert Camus, ${ }^{23}$ that choosing freedom is not choosing something against justice. Instead freedom is chosen because the people who suffer and struggle for justice. Separating freedom from justice is a social sin. Freedom must be filled by prioritizing obligations rather than rights and then used to serve justice. Humans as autonomous beings talk of freedom are about human dignity itself, which is why coercion that we feel is not only painful but also an insult, therefore coercion means the neglect of human dignity.

According to Yahya Harahap, 24 that the freedom of judge must not be interpreted as unlimited freedom by emphasizing the arrogance of power by using freedom to justify any means, but that freedom is relative with refers to:

a. Applying the law from the right and correct laws and regulations in resolve cases that are being examined, in accordance with the principles and statute law must prevail (the provisions of the law must be superior);

21 Elena Kantorowicz-Reznichenko. (2017). "Misidentification of victims under international criminal law: an attempted offence?." Journal of International Criminal Justice, Vol. 15, No. 2: 291-318.

22 Harahap, M.Y. (2005). Kedudukan Kewenangan dan Acara Peradilan Agama, Sinar Grafika, Jakarta, p. 28.

23 Camus, A. (1988) Krisis Kebebasan (Terjemahan: Edhi Martono), Jakarta: Yayasan Obor, p.75.

24 Harahap. Op. Cit, pp. 60-61 
b. Interpreting the right law through the approaches of justified interpretations (systematic, sociological, linguistic, analogous and acontrario) or prioritize justice rather than statutory regulations, if the provisions of the law do not have the potential to protect the public interest. Such application is in accordance with the doctrine of equity must prevail (justice must be superior);

Freedom to seek and find law (rechtsvinding), the basics and principles of law through the doctrine of legal science, unwritten legal norms (customary law), jurisprudence or through the "realism" approach that is looking for and finding laws that are based on economic, moral, religion, propriety and custom values.

Departing from the construction of the law, the most important thing to be understood by the public is that the judiciary in Indonesia is a State court, not a people court let alone a street court. The trial is applied "for the sake of justice based on the almighty God" not justice for the king or queen or for the president or the Supreme Court but solely for the sake of law and justice for all people with various backgrounds. It shows that justice in Indonesia has a transcendental dimension. Justice in Indonesia has an egalitarian spirit, because it must not discriminate between people or what is known as the expression "equality before the law", or also called "equal justice under law".

\section{Conclusion}

Impartial legal process (free from pressure, both physical and psychological and impartial) is a characteristic of a constitutional State. In the criminal justice system has received a full principle of free and impartial justice. At the lowest level, this principle in criminal justice is played by the judge as the core apparatus of judicial power, the principle of freedom and impartiality of judges in examining, hearing and deciding cases. The treatment in a crime must always be brought to the application of the principle of impartiality or treatment as referred in the principles of impartiality. Likewise, the principle of impartiality must not only be applied to suspects or defendants, it must be interpreted including the treatment of crown witnesses, victim witnesses and their families and also cannot be ignored about the existence of the community as legal subjects who have an interest in the implementation of public law. Therefore, the construction of social life is not possible to success if not accompanied by the law development and enforcement that is independent and just.

\section{References}

Journal Articles:

Bawangun, A. (2014). "Pertanggungjawaban Kode Etik Hakim dalam Memutuskan Perkara Pidana." Lex Crimen Vol. 3, No. 2: 86-92.

Contini, F., \& Mohr, R. (2007). Reconciling independence and accountability in judicial systems. Utrecht L. Rev., 3, 26.

Elena Kantorowicz-Reznichenko. (2017). "Misidentification of victims under international criminal law: an attempted offence?." Journal of International Criminal Justice, 15 (2): 291-318.

Larkins, C.M. (1996). Judicial Independence and Democratization: A Theoretical and Conceptual Analysis. The American Journal of Comparative Law. Vol XLIV (4).

Mochtar, Z.A. (2015). "Antinomi dalam Peraturan Perundang-undangan di Indonesia." Hasanuddin Law Review, 1 (3): 316-36. 
Sibarani, S. (2018). Analisis Hukum Terhadap Korban Salah Tangkap (Error In Persona) Dalam Putusan No. 2161 K/PID/2012, Jurnal Justitia et Pax, Vol 34, No 2: 271-88.

Sorik, S., Nasution, M., and Nazaruddin. (2018). "Eksistensi Majelis Kehormatan Mahkamah Konstitusi (Studi Keputusan Majelis Kehormatan Mahkamah Konstitusi Nomor 01/MKMK/ X/2013)." Jurnal Konstitusi Vol. 15, No. 3: 666-87.

Tardjono, H. (2016). "Reorientasi Politik Hukum Pembentukan Undang-Undang di Indonesia." Jurnal Renaissance, 1 (2): 61-74.

Books:

Adiyaryani, N.N. (2017). Asas Independensi dan Imparsialitas Hakim Menurut Sistem Peradilan Pidana. Postgraduate Program, Brawijaya University.

Arief, B.N. (2001). Masalah Penegakan Hukum \& Kebijakan Penanggulangan Kejahatan. Bandung: Citra Aditya Bakti.

Asshiddiqie, J. (2006). Pengantar Ilmu Hukum Tata Negara Jilid II. Jakarta: Sekretariat Jenderal dan Kepaniteraan Mahkamah Konstitusi RI.

Camus, A. (1988) Krisis Kebebasan (Terjemahan: Edhi Martono), Jakarta: Yayasan Obor.

Goesniadhie, K. (2009). Prinsip Pengawasan Independensi Hakim. Makalah Hukum. Fakultas Hukum Universitas Wisnuwardhana. Malang.

Harahap, M.Y. (2005). Kedudukan Kewenangan dan Acara Peradilan Agama, Sinar Grafika, Jakarta.

Ibrahim, J. (2005). Teori dan Metode Penelitian Hukum Normatif, Malang: Bayumedia Publishing.

Manan, B. (1995). Kekuasaan Kehaikman Republik Indonesia. Bandung: Pusat Penerbitan Universitas LPPM Universitas Islam Bandung.

Mertukusomo, S. (2005). Mengenal Hukum, Suatu Pengantar, Liberty, Yogyakarta.

Muchsin. (2004), Kekuasaan Kehakiman yang Merdeka \& Kebijakan Asasi, STIH IBLAM, Depok.

Rahardjo, S. (2010). Penegakan Hukum Progresif, Kompas, Jakarta.

Rima, F. (2019). "Fatamorgana Keadilan Hukum Dalam Prinsip The Rule of Law." Pergulatan Etika Indonesia, Seri Filsafat Atmajaya.

Robbers, G. (2003). An Introduction to German Law, 2003, 3 th ed.

\section{Conflict of Interest Statement:}

The author(s) declares that the research was conducted in the absence of any commercial or financial relationships that could be construed as a potential conflict of interest.

Copyright (C) 2020 HALREV. All rights reserved. 